\title{
Immunoreactivity with the Anti-MAGE Antibody 57B in Malignant Melanoma: Frequency of Expression and Correlation with Prognostic Parameters
}

\author{
Klaus J. Busam, M.D., Kristin Iversen, B.S., Marianne Berwick, Ph.D, Guilio C. Spagnoli, Ph.D., \\ Lloyd J. Old, M.D., Achim A. Jungbluth, M.D. \\ Department of Pathology (KJB), Ludwig Institute for Cancer Research, New York Branch (KI, LJO, AAJ), \\ and Department of Epidemiology and Biostatistics (MB), Memorial Sloan-Kettering Cancer Center, New \\ York, New York; and Department of Surgery, University Hospital (GCS), Basel, Switzerland
}

The melanoma-associated antigen (MAGE) family consists of a number of antigens initially recognized by cytotoxic $\mathrm{T}$ lymphocytes, which are currently being investigated for immunotherapy of patients with metastatic melanoma and other tumor types. Expression of MAGE mRNA in melanocytic tumors is said to be restricted to invasive malignant tumors and absent in nevi. Recently, a monoclonal antibody (57B) has become available to examine MAGE protein expression in archival material. In this study, we performed immunohistochemical analysis on 132 melanocytic nevi and 205 melanomas (85 primary cutaneous melanomas and 120 metastatic tumors) to determine the frequency of MAGE expression and to explore a potential correlation with various prognostic parameters. None of the melanocytic nevi and none of the 20 in situ melanomas was immunopositive with the antibody $57 \mathrm{~B}$. Immunoreactivity was present in 17 of $65(26 \%)$ primary invasive melanomas of the skin and in 30 of 120 (25\%) metastatic tumors. Positive immunostaining did not correlate with tumor stage $(P=.66)$, Breslow thickness $(P=.39)$, Clark level $(P=.5)$, or the histologic type of melanoma $(P=.23)$ but was associated with a brisk infiltrate of lymphocytes involving the vertical growth phase of melanomas $(P=.01)$. Because tumor-infiltrating lymphocytes in melanoma are associated with longer survival, our findings suggest a potential prognostic role for MAGE. Furthermore, the seeming restriction of immunopositivity to invasive malignant tumors suggests a potential diagnostic role for the antibody

Copyright (C) 2000 by The United States and Canadian Academy of Pathology, Inc

VOL. 13, NO. 4, P. 459, 2000 Printed in the U.S.A.

Date of acceptance: September 15, 1999.

Address reprint requests to: Klaus J. Busam, M.D., Department of Pathology, Memorial Sloan-Kettering Cancer Center, 1275 York Avenue, New York, NY 10021; e-mail: busamk@mskcc.org; fax: 212-717-3203.
57B in confirming the malignant potential of a melanocytic tumor.

KEY WORDS: Immunohistochemistry, Melanoma, MAGE, Tumor-infiltrating lymphocytes.

Mod Pathol 2000;13(4):459-465

Human cancer cells express tumor-rejection antigens in an HLA-restricted fashion, which are recognized by cytotoxic $\mathrm{T}$ lymphocytes (1-3). Several genes that encode such antigens have been cloned. A family of melanoma-associated antigens (MAGE) has been defined $(4-12)$ and consists of 17 genes (11). Several of them, such as MAGE-1, -3, -4, -6, and -12 , have been shown to be expressed only in malignant tumors and seem to be absent in normal tissue except for testis and placenta $(3,7)$. MAGE-2 and -3 are the most abundantly expressed members of this family in malignant melanoma, and MAGE-3 has been particularly well studied $(6,9,10,13,14)$.

Like other MAGE genes, MAGE-3 expression is not limited to malignant melanoma; it also is present in a number of other malignant tumors, such as carcinomas of the lung (15), colorectum (16), and bladder (17). Although most MAGE expression studies to date are based on reverse transcriptase-polymerase chain reaction (RT-PCR) analysis, a monoclonal antibody (57B) has recently become available and allows analysis of protein expression (13). This antibody was said to be specific for MAGE-3 $(13,18)$. However, recent evidence suggests that it also recognizes other members of the MAGE family, including MAGE-1, -4, -6, and -12 (D. Rimoldi, personal communication, December 1998; personal observations, December 1998), and is better regarded as a multi-MAGE antibody.

Insight into MAGE protein expression is relevant for the development of immunotherapeutic strategies against malignant melanoma (19-22). However, MAGE protein expression may also be of in- 
terest as a potential diagnostic or prognostic parameter. If it is true that MAGE genes are absent in melanocytic nevi and malignant melanoma in situ but commonly expressed in invasive melanomas $(10,18)$, then immunoreactivity with the antibody 57B may be used to support the malignant nature of a diagnostically difficult lesion.

Before such a potential diagnostic use of the antibody 57B can be evaluated, however, it is important to confirm the lack of immunostaining in a large number of melanocytic nevi. It is also critical to assess the frequency of immunopositivity in malignant melanoma by studying a large number of melanomas with good documentation of their pathologic features. To this end, we studied 132 nevi and 205 melanomas, which represents the largest immunohistochemical study with the antibody 57B in archival tissue to date. Another purpose of our study was to explore a potential prognostic role for the antibody $57 \mathrm{~B}$ by comparing immunopositivity in primary cutaneous malignant melanomas with various histologic prognostic parameters, including Breslow thickness, Clark level, histologic type, and the density of lymphocytes involving the vertical growth phase of primary melanomas. Whereas MAGE expression has been compared with tumor stage in previous studies $(10,18)$, a possible association with tumor-infiltrating lymphocytes has not been analyzed before.

\section{MATERIALS AND METHODS}

All tissue samples were retrieved from the archives of the Department of Pathology at Memorial Sloan-Kettering Cancer Center. All tissue blocks had been fixed in formalin and were embedded in paraffin. A hematoxylin and eosin-stained section of each lesion was reviewed by one dermatopathologist (KJB) to verify the diagnosis, to assess the presence of representative lesional material, and to record histologic parameters, including thickness, Clark level, the density of tumorinfiltrating lymphocytes, and the histologic subtype.

The thickness of primary melanomas was measured using an ocular micrometer according to the method of Breslow (23). All invasive melanomas contained a vertical growth phase as defined by Clark et al., (24) Elder et al., (25) and Elder and Murphy (26). The lymphocytes infiltrating the vertical growth phase of primary cutaneous melanomas were categorized as "absent," "non-brisk," and "brisk." Tumor-infiltrating lymphocytes were termed "brisk" when the lymphocytes were present throughout the vertical growth phase (diffuse) or were present and infiltrating (i.e., separating and surrounding melanoma cells) along the entire base of the vertical growth phase (peripheral). The category "non-brisk" was used when lymphocytes were present in one or more foci but not throughout the entire vertical growth phase. The term "absent" was used when there were minimal or no lymphocytes or when they were present but did not infiltrate into the vertical growth phase. Histologic subtyping was done according to Clark $(27,28)$. The guidelines of the American Joint Committee on Cancer were used for staging (29).

Unstained 5- $\mu \mathrm{m}$-thick sections corresponding to the tumor foci seen in routine sections were chosen for immunohistochemical analysis with the antibody 57B. This IgG1 murine monoclonal antibody was previously characterized $(13,18)$ and was used at a final concentration of $1 \mu \mathrm{g} / \mathrm{mL}$. Testicular tissue served as positive control. Antigen retrieval was achieved using a steam autoclave $\left(121^{\circ} \mathrm{C}\right.$ for 10 $\mathrm{min}$ ) as the heating source and a low-concentration citrate buffer ( $\mathrm{pH}$ 6.0, $10 \mathrm{~mm})$ as the retrieval solution.

Detection of the primary antibody was achieved by using biotinylated secondary horse anti-mouse antibody (1:200; Vector Laboratories, Burlingame, CA) and an avidin-biotin horseradish peroxidase complex (Vector Laboratories). Diaminobenzidine tetrahydrochloride (Biogenex, San Ramon, CA) was the chromogen, and endogenous peroxidase was suppressed with $1 \%$ hydrogen peroxide treatment for $30 \mathrm{~min}$. Results were recorded without knowledge of clinical parameters.

Statistical analysis of 65 primary invasive cutaneous melanomas was performed using SAS (Sas Institute, Version 6.11, Cary, NC). Comparisons of variables by the presence or absence of immunoreactivity with the antibody 57B were made using the Kruskal Wallis test ( $\chi^{2}$ approximation) and the Wilcoxon two-sample test for Breslow thickness as this variable was not normally distributed. Two-tailed tests of significance were used.

\section{RESULTS}

\section{Frequency of Expression}

\section{Melanocytic nevi}

Of 132 melanocytic nevi, not a single lesion revealed any immunoreactivity with the antibody 57B. We examined 10 ordinary junctional nevi, 40 ordinary compound nevi, 10 dermal nevi, 43 dysplastic nevi (compound melanocytic nevi with architectural disorder and atypia or Clark's nevi), 5 congenital compound nevi, 10 Spitz nevi (nevi of large spindle and/or epithelioid melanocytes), 5 pigmented spindle cell nevi, 4 blue nevi, and 3 acral compound nevi. Two nevi in the capsule of lymph nodes were also examined and found to be immunonegative with the antibody $57 \mathrm{~B}$. 


\section{Primary cutaneous melanoma}

Eighty-five primary cutaneous melanomas were examined, including 20 in situ and 65 invasive tumors in vertical growth phase. All 20 in situ melanomas were immunonegative. Seventeen invasive tumors were immunopositive (Table 1). Immunoreactivity with the antibody 57B was present in both intraepidermal and dermal melanoma cells (Fig. 1A). In all 14 non-nodular primary tumors, immunopositivity was present in melanoma cells of both the radial and the vertical growth phases. The staining was predominantly cytoplasmic, but occasional nuclear staining was also seen (Fig. 1B). The proportion of immunoreactive cells within a primary malignant melanoma varied. In the majority of positive tumors (nine cases), there was homogeneous staining of most ( $>90 \%$ ) melanoma cells (Fig. 1). In four cases, 50 to $75 \%$ of melanoma cells were positive; in three lesions, 25 to $50 \%$ of tumor cells were positive; and in one melanoma, fewer than $5 \%$ of tumor cells were immunopositive. A primary nodular melanoma with only a minor subpopulation (approximately 30\%) of tumor cells immunopositive with the antibody 57B is illustrated in Fig. 2.

\section{Metastatic melanoma}

Lymph node, cutaneous, and internal (i.e., visceral or brain) metastases from 120 patients were examined. The findings are summarized in Table 1. Only one representative metastasis from each patient was included in this table. Thus, each metastasis corresponds to a different patient. Thirty of 120 metastases $(25 \%)$ were immunopositive with the antibody 57B (Table 2). In 21 metastases, positive staining was present in the majority of tumor cells: 15 metastases had more than $75 \%$ positive tumor cells (Figs. 3A and B), and 6 metastases had 50 to $75 \%$ positive tumor cells. Nine tumors contained fewer than 50\% immunopositive melanoma cells: six metastases had 25 to $50 \%$ positive tumor cells, and three metastases had fewer than $25 \%$ positive tumor cells. A lymph node metastasis with only a minor subpopulation immunoreactive with 57B is illustrated in Figure 3C. Immunoreactivity was slightly more commonly observed in skin metastases than at extracutaneous sites: 10 of 33 (30\%) cutaneous metastases were immunopositive,

TABLE 1. Immunoreactivity with 57B in Primary and Metastatic Malignant Melanoma $(n=205)$

\begin{tabular}{lcc}
\hline \multicolumn{1}{c}{ Tumor Type } & No. Tumors Tested & Positive (\%) \\
\hline Primary in situ & 20 & $0(0)$ \\
Primary invasive & 65 & $17(25)$ \\
Metastases & 120 & $30(25)$ \\
To skin & 33 & $10(30)$ \\
To lymph nodes & 66 & $15(23)$ \\
To internal sites & 21 & $5(24)$ \\
(visceral or brain) & & \\
\hline
\end{tabular}

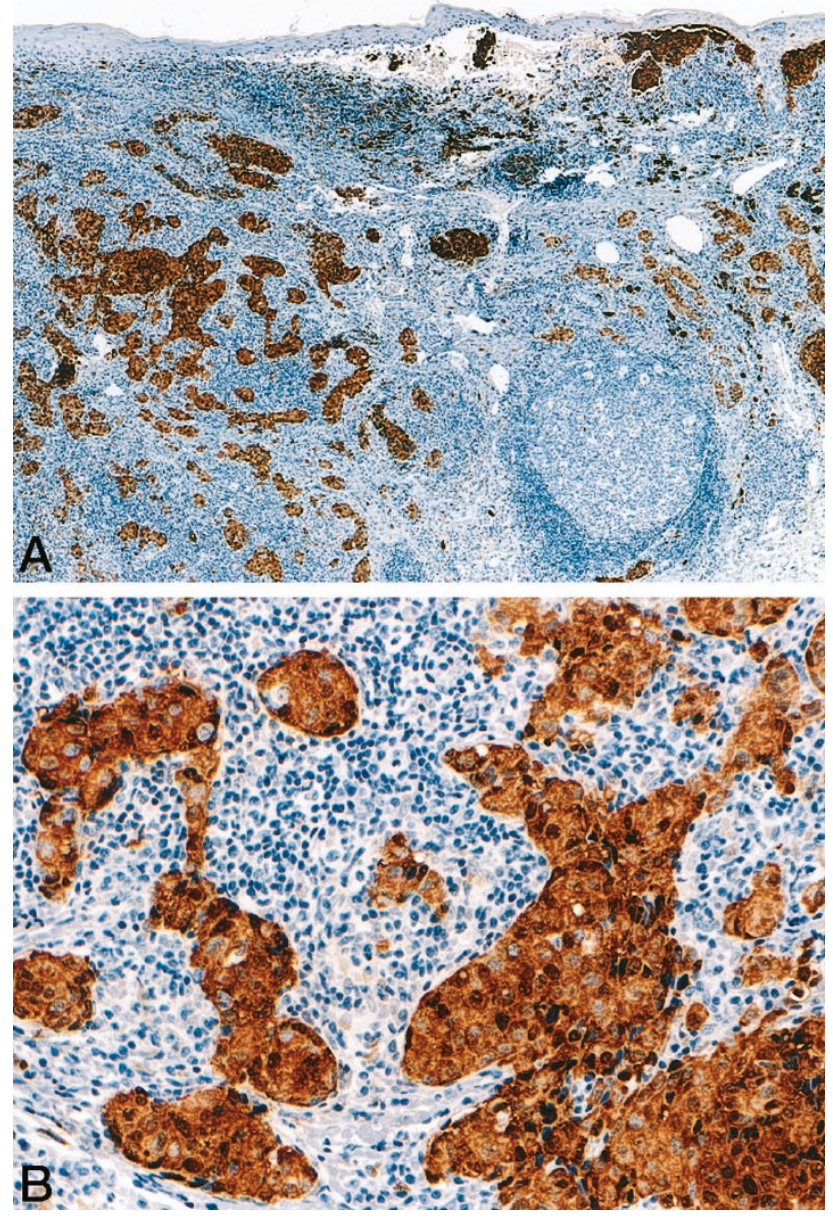

FIGURE 1. Homogeneous immunoreactivity with the antibody 57B in a primary melanoma. A, strong positive staining is seen in all melanoma cells along the dermoepidermal junction and in the dermis. The invasive dermal component is completely surrounded and extensively infiltrated by numerous lymphocytes. A lymphoid follicle with a reactive germinal center is also present. $\mathbf{B}$, immunostaining is mainly cytoplasmic, but occasional nuclear staining is also seen.

whereas 15 of 66 (23\%) lymph node and 5 of 21 (24\%) internal metastases were positive. In seven patients, two metastatic tumors from the same patient were studied. In three of the seven patients, both tumors were immunopositive, whereas in four patients, both tumors were negative with the antibody $57 \mathrm{~B}$.

\section{Comparison of MAGE Expression with \\ Prognostic Factors and Histologic Type}

Sixty-five primary cutaneous invasive melanomas were stratified according to histologic type and prognostic parameters, including Breslow thickness, Clark level, and the density of the lymphocytic infiltrate involving the vertical growth phase of the melanoma. These features were compared with immunoreactivity with the antibody 57B. As illustrated in Table 2, positive staining was associated only with a brisk lymphocytic infiltrate $(P=.01)$ but not with Breslow thickness $(P=.39)$, Clark level 


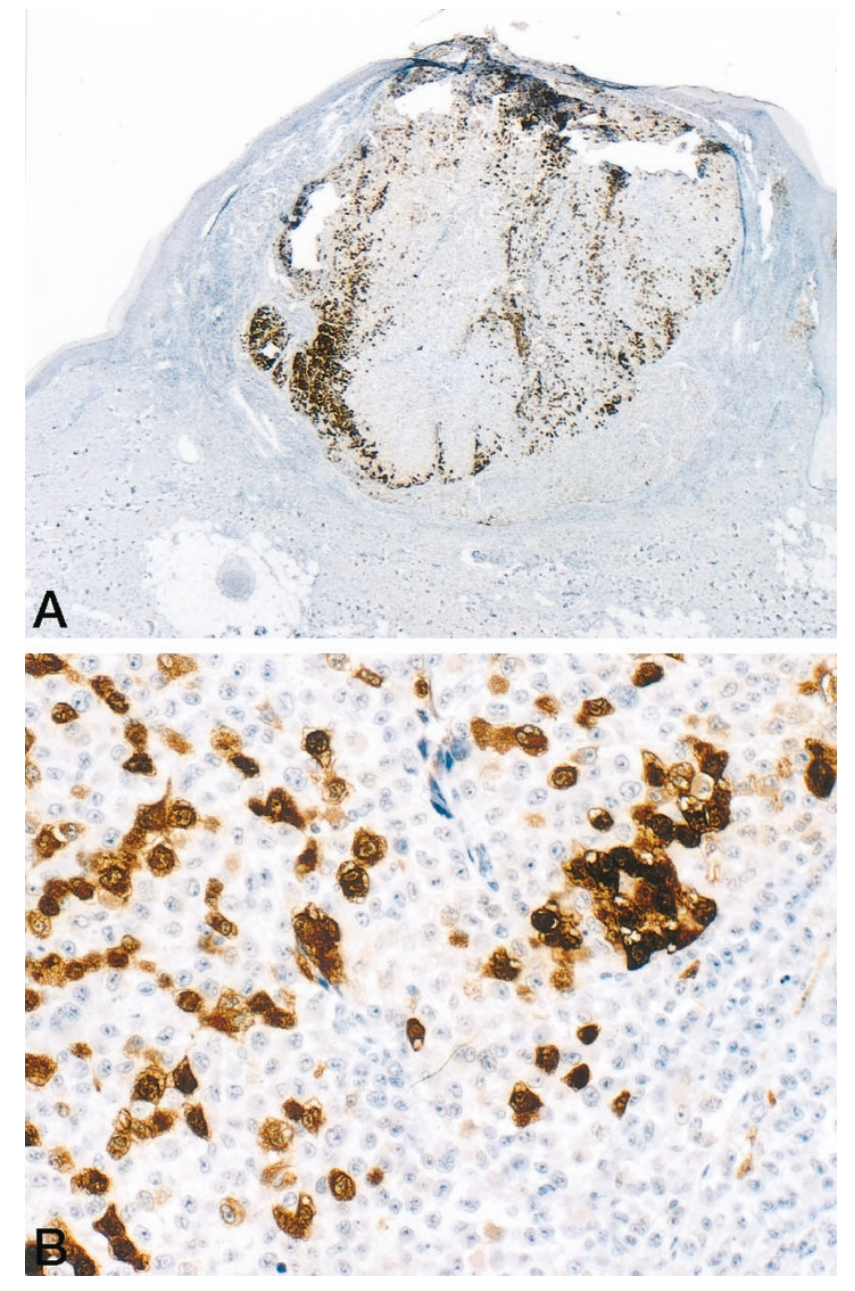

FIGURE 2. Heterogeneous immunoreactivity with the antibody 57B in a primary nodular melanoma (see Fig. 3C for corresponding lymph node metastasis). A, positive staining is seen only in a minority of tumor cells. B, immunoreactivity of individual tumor cells varies from faint cytoplasmic to strong cytoplasmic and nuclear staining.

$(P=.5)$, or histologic type $(P=.23)$. A primary cutaneous melanoma of superficial spreading type with a brisk infiltrate of lymphocytes involving its vertical growth phase, which was immunoreactive with the antibody 57B, is illustrated in Figure 1.

\section{DISCUSSION}

Human melanoma cells express several antigens, which are recognized by cytotoxic $\mathrm{T}$ lymphocytes, and the genes of a number of such antigens have been identified, such as members of the MAGE, BAGE, or GAGE gene families, gp100, tyrosinase, Melan-A, NY-ESO1, and others (1-3, 30). Some of these antigens are being investigated as targets for immunotherapy of metastatic melanoma (19-22, 31 ), and some of them have been examined for diagnostic purposes (32-37).

Previous studies on MAGE expression in malignant melanoma were predominantly based on RT-PCR studies $(8,10,14)$. They suggested that
TABLE 2. Comparison of Histopathologic Features with Presence or Absence of Immunoreactivity with 57B in 65 Primary Invasive Melanomas

\begin{tabular}{|c|c|c|c|}
\hline \multirow{2}{*}{ Features } & \multicolumn{2}{|c|}{ Immunoreactivity } & \multirow{2}{*}{$\begin{array}{c}P \\
\text { Value }\end{array}$} \\
\hline & Present & Absent & \\
\hline \multicolumn{4}{|l|}{ Tumor stage } \\
\hline pT1 & 4 & 15 & \\
\hline pT2 & 3 & 4 & \\
\hline pT3 & 8 & 16 & \\
\hline pT4 & 2 & 13 & 0.66 \\
\hline \multicolumn{4}{|l|}{ Clark level } \\
\hline II & 5 & 15 & \\
\hline III & 2 & 3 & \\
\hline IV & 9 & 20 & \\
\hline $\mathrm{V}$ & 1 & 10 & 0.5 \\
\hline \multicolumn{4}{|l|}{ Histopathologic type } \\
\hline Superficial spreading & 11 & 24 & \\
\hline Nodular & 3 & 9 & \\
\hline Lentigo maligna/desmoplastic & 0 & 8 & \\
\hline Neurotropic & 0 & 1 & \\
\hline Acral lentiginous/ungual & 3 & 6 & 0.23 \\
\hline \multicolumn{4}{|l|}{ Lymphocytic infiltrate } \\
\hline Absent & 1 & 15 & \\
\hline Non-brisk & 12 & 30 & \\
\hline Brisk & 4 & 3 & 0.01 \\
\hline Mean Breslow thickness (SD) & $\begin{array}{l}2.16 \\
(1.56)\end{array}$ & $\begin{array}{l}2.72 \\
(3.64)\end{array}$ & 0.39 \\
\hline
\end{tabular}

MAGE genes-in particular, MAGE-1, -2, and -3were commonly expressed in invasive and metastatic melanoma but absent in melanocytic nevi. In the study by Brasseur et al. (10), approximately $50 \%$ of primary cutaneous melanomas and $83 \%$ of metastatic tumors were said to express at least one MAGE gene by RT-PCR, and an association of MAGE expression with advanced tumor stage was suggested. In a more recent study, however, a lower frequency of MAGE gene expression was found: Sahin and coworkers (14) detected MAGE mRNA only in approximately $50 \%$ of metastatic melanomas. Recently, the monoclonal antibody 57B has become available to study MAGE protein expression in human tissue (18). According to Hofbauer et al. (18), who examined a limited number of primary and metastatic melanomas, $40 \%$ of their tumors were immunopositive.

In our study, the frequency of immunoreactivity with the antibody 57B in malignant melanoma was only $25 \%$. We believe that sample bias is the most likely explanation for why we found fewer 57Bimmunopositive melanomas than Hofbauer et al. (18) did. We used the same clone of antibody and similar immunohistochemical techniques, but the number of cases examined by Hofbauer et al. (18) was much smaller than in our study. Furthermore, they did not distinguish cutaneous from nodal or visceral metastases, and they did not indicate whether each metastasis corresponded to a different patient or several metastatic tumors from the same patient were included for their analysis (18). Such distinctions, however, are necessary because multiple tumors from the same patient tend to have a similar MAGE expression pattern (10). 


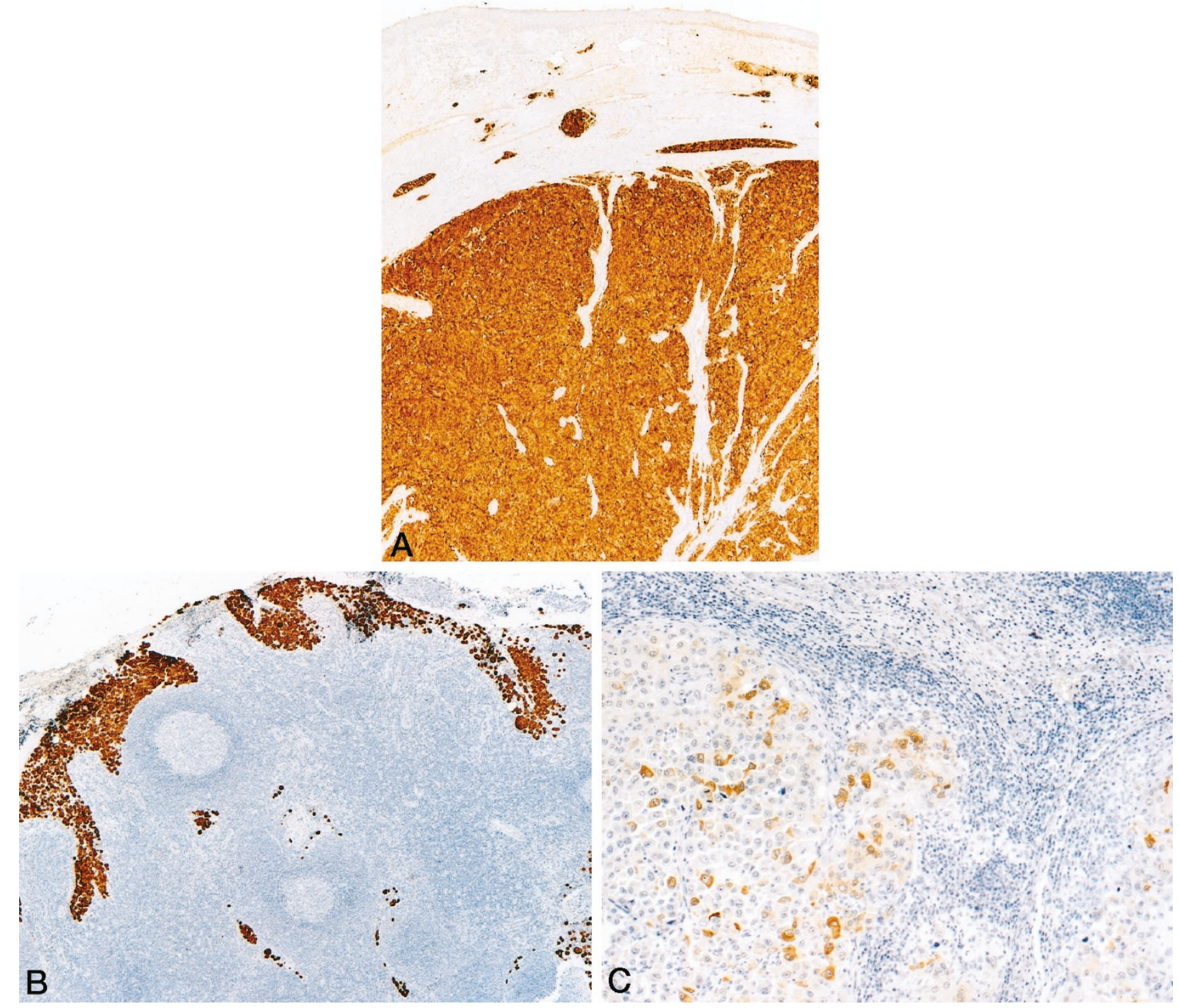

FIGURE 3. Immunoreactivity with the antibody 57B in metastatic melanoma. A, metastatic melanoma to the skin. The tumor cells are uniformly positive. B, metastatic melanoma in lymph node. The tumor cells are uniformly positive. C, metastatic melanoma in lymph node. Only a subpopulation of metastatic tumors cells is immunoreactive (see Fig. 2 for corresponding primary cutaneous melanoma).

Because none of the nevi or in situ melanomas in our series or in any previous study was immunoreactive with the antibody $57 \mathrm{~B}$, we believe that this antibody may emerge as a diagnostic tool to support the malignant potential of some unusual melanocytic tumors. Unfortunately, in our study, immunoreactivity with 57B was detectable in only $25 \%$ of "conventional" primary invasive melanomas, which indicates that its potential diagnostic use will be limited.

Hofbauer and colleagues (18) also suggested a correlation between immunoreactivity with the antibody 57B and tumor stage. They examined 31 primary invasive melanomas, and all 4 melanomas staged as pT4a ( $>4 \mathrm{~mm}$ thick, Clark level V) were said to be immunopositive. The authors did not perform a formal statistical analysis of their data. We examined 65 primary invasive melanomas; only
2 of 15 pT4a melanomas were immunopositive with 57B and only in a minor subpopulation of cells (Fig. 2). A statistical analysis of the findings in our series failed to reveal an association between immunoreactivity and tumor stage, Breslow thickness, or Clark level (Table 2). The lack of an overall increase in frequency of immunoreactivity from primary invasive cutaneous melanoma to metastatic melanoma, not even to internal (visceral and brain) metastases, also argues against a simple, direct association of immunoreactivity with advanced disease stage (Table 1).

A direct comparison between primary and metastatic tumors in the same patient was limited by the insufficient number of patients with immunopositive tumors, in which both primary and metastatic tumors were available. In many patients with immunopositive metastases, the primary site was un- 
known (metastatic melanoma of unknown primary site) or the tissue block of the most representative lesional tissue of the primary tumor could not be obtained from outside institutions for investigational studies. Furthermore, only one of the primary 57B-immunopositive melanomas in this series has so far metastasized. In this patient, both the primary (Fig. 2) and the metastatic (Fig. 3C) tumor contained only a minor subpopulation of $57 \mathrm{~B}$ positive cells. In another case, in which a minor subpopulation of the metastatic tumor was immunopositive, the primary melanoma lacked any detectable immunoreactivity with 57B. In all 57Bnegative tumors, in which the tissue blocks of both the primary melanoma and the corresponding metastasis were available, both tumors were immunonegative.

The most important finding in our study is an association of MAGE expression in primary cutaneous melanoma with a brisk infiltrate of lymphocytes involving the vertical growth phase. Such an association is of interest not only because it may provide a clue to the understanding of the biologic mechanisms underlying the phenomenon of tumor-infiltrating lymphocytes but also because it raises the possibility of a potential prognostic role for MAGE proteins. Several investigators have suggested a prognostic role of the lymphocytic infiltrate in melanoma $(24-26,38-40)$. In multivariate analyses of clinical Stage I melanomas by the Pigmented Lesion Study Group at the University of Pennsylvania, the presence of a brisk infiltrative lymphocytic response was found to be associated with favorable survival $(24,25)$. More recent, Clemente and coworkers (40) have presented data confirming the prognostic value of tumorinfiltrating lymphocytes in primary melanomas.

Two recent studies have also examined tumorinfiltrating lymphocytes in metastatic tumors and revealed evidence that patients had a longer disease-free survival, if their metastatic tumor deposits were involved by a brisk lymphocytic infiltrate $(41,42)$. In contrast with primary tumors, we did not find a correlation between 57B immunopositivity and the density of the lymphocytic infiltrate of metastatic tumor deposits. The majority of metastases in our series lacked a significant lymphocytic infiltrate. None of the visceral or cutaneous metastases had a brisk lymphocytic infiltrate.

In conclusion, we confirm in this study that MAGE expression as detected by immunoreactivity with the antibody 57B is absent in nevi and noninvasive melanomas and find that immunopositivity of primary cutaneous melanomas correlates with brisk tumor-infiltrative lymphocytes but not with other examined prognostic indicators. These results encourage further exploration of the potential diagnostic and prognostic value of the antibody 57B.
Acknowledgments: We are grateful to Keren Coplan and Janet Braunstein for their excellent technical support.

\section{REFERENCES}

1. Boon T, Old LJ. Tumor antigens. Cur Opin Immunol 1997;9: 681-3.

2. Boon T, Vanderbruggen P. Human tumor antigens recognized by T lymphocytes. J Exp Med 1996;183:725-9.

3. Van Pel A, van der Bruggen P, Coulie PG, Brichard VG, Lethe $\mathrm{B}$, van den Eynde B, et al. Genes coding for tumor antigens recognized by cytolytic T lymphocytes. Immunol Rev 1995; 145:229-50.

4. Van der Bruggen P, Traversari C, Chomez P, Lurquin C, De Plaen E, Van den Eynde B, et al. A gene encoding an antigen recognized by cytolytic $\mathrm{T}$ lymphocytes on a human melanoma. Science 1991;254:1643-7.

5. Traversari C, van der Bruggen P, Van den Eynde B, Hainaut $\mathrm{P}$, Lemoine $\mathrm{C}$, Ohta $\mathrm{N}$, et al. Transfection and expression of a gene coding for a human melanoma antigen recognized by autologous cytolytic T lymphocytes. Immunogenetics 1992; 53:145-52.

6. Van der Bruggen P, Bastin J, Gajewski T, Coulie PG, Boel P, De Smet C, et al. A peptide induced by human gene MAGE-3 and presented by HLA-A2 induces cytolytic T lymphocytes that recognize tumor cells expressing MAGE-3. Eur J Immunol 1994;24:3038-43.

7. De Plaen E, Arden K, Traversari C, Gaforio JJ, Szikora JP, De Smet C, et al. Structure, chromosomal localization, and expression of 12 genes of the MAGE family. Immunogenetics 1994;40:360-9.

8. Gaugler B, Van den Eynde B, Brasseur F, Boon T. Human gene MAGE-3 codes for antigen recognized on a melanoma by autologous cytolytic T lymphocytes. J Exp Med 1994;179: 921-30.

9. Van den Eynde B, Peeters O, DeBacker O, Gaugler B, Lucas S, Boon T. A new family of genes coding for an antigen recognized by autologous cytolytic T lymphocytes on human melanoma. J Exp Med 1995;182:689-98.

10. Brasseur F, Rimoldi D, Lienard D, Lethe B, Carrel S, Arienti F, et al. Expression of MAGE genes in primary and metastatic cutaneous melanoma. Int J Cancer 1995;63:375-80.

11. Lucas S, DeSmet C, Arden KC, Viars CS, Lethe B, Lurquin C, et al. Identification of a new MAGE gene with tumor-specific expression by representational difference analysis. Cancer Res 1998;58:743-52.

12. Jurk M, Kremmer E, Schwarz U, Forster R, Winnacker FL. MAGE-11 protein is highly conserved in higher organisms and located predominantly in the nucleus. Int J Cancer 1998;75:762-6.

13. Kocher T, Schultz-Thater E, Gudat F, Schaefer C, Casorati G, Juretic A, et al. Identification and intracellular location of MAGE-3 gene product. Cancer Res 1995;55:2236-9.

14. Sahin U, Turect O, Chen YT, Seitz G, Villena-Heinsen C, Old LJ, et al. Expression of multiple cancer/testis antigens in breast cancer and melanoma: basis for polyvalent CT vaccine strategies. Int J Cancer 1998;78:387-9.

15. Weynants P, Lethe B, Brasseur F, Marchand M, Boon T. Expression of MAGE genes by non-small cell lung carcinomas. Int J Cancer 1994;56:826-9.

16. Mori M, Inoue H, Mimori K, Shibuta K, Baba K, Nakashima $\mathrm{H}$, et al. Expression of MAGE genes in human colorectal carcinoma. Ann Surg 1996;224:183-8.

17. Patard J-J, Brasseur F, Gil-Diez S, Radvanyi F, Marchand M, Francois P, et al. Expression of MAGE genes in transitional cell carcinomas of the urinary bladder. Int J Cancer 1995;64: $60-4$. 
18. Hofbauer GFL, Schaefer C, Noppen C, Boeni R, Kamarashev, Nestle FO, et al. MAGE-3 immunoreactivity in formalinfixed, paraffin-embedded primary and metastatic melanoma. Am J Pathol 1997;151:1549-53.

19. Marchand M, Weynants P, Rankin E, Arienti F, Belli F, Parmiani G, et al. Tumor regression responses in melanoma patients treated with a peptide encoded by gene MAGE-3. Int J Cancer 1995;63:883-5.

20. Maeurer MJ, Storkus WJ, Kirkwood JM, Lotze MT. New treatment options for patients with melanoma: review of melanoma-derived T-cell epitope-based peptide vaccines. Melanoma Res 1996;6:11-24.

21. Gattoni-Celli S, Cole DJ. Melanoma-associated tumor antigens and their clinical relevance to immunotherapy. Semin Oncol 1996;23:754-8.

22. Rosenberg SA. The immunotherapy of solid cancers based on cloning the genes encoding tumor-rejection antigens. Annu Rev Med 1996;47:481-91.

23. Breslow A. Thickness, cross-sectional area and depth of invasion in the prognosis of cutaneous melanoma. Ann Surg 1970;172:902-8.

24. Clark WH Jr, Elder DE, Guerry DP IV, Braitman LE, Trock BJ, Schultz D, et al. Model predicting survival in stage I melanoma based on tumor progression. J Natl Cancer Inst 1989; 81:1893-904.

25. Elder DE, Guerry D IV, VanHorn M, Hurwitz S, Zehngebot L, Goldman LI, et al. The role of lymph node dissection for clinical stage I malignant melanoma of intermediate thickness (1.51-3.99 mm). Cancer 1985;56:413-8.

26. Elder DE, Murphy GF. Malignant tumors (melanomas and related lesions). In: Elder DE, Murphy GF, editors. Melanocytic tumors of the skin. Atlas of Tumor Pathology. Washington, DC: Armed Forces Institute of Pathology; 1990. pp. 103-205.

27. Clark WH Jr, Elder DE, Van Horn M. The biologic forms of malignant melanoma. Hum Pathol 1986;17:443-50.

28. McGovern VJ, Mihm MC Jr, Bailly C, Booth JC, Clark WH Jr, Cochran AJ, et al. The classification of malignant melanoma and its histologic reporting. Cancer 1973;32:1446-57.

29. American Joint Committee on Cancer. Manual for staging of cancer (4th ed.), Philadelphia: J.B. Lippincott; 1992. pp. $143-8$.

30. Chen YT, Gure AO, Tsang S, Stockert E, Jager E, Knuth A, et al. Identification of multiple cancer/testis antigens by allogeneic antibody screening of a melanoma cell line library. Proc Natl Acad Sci U S A 1998;95:6919-23.

31. Spagnoli GC, Schaefer C, Willimann TE, Kocher T, Amoroso A, Juretic A, et al. Peptide-specific CTL in tumor-infiltrating lymphocytes from metastatic melanomas expression MART1/Melan-A, gp100 and tyrosinase genes: a study in an un- selected group of HLA-A2.1-positive patients. Int J Cancer 1995;65:309-15.

32. Busam KJ, Iversen K, Coplan KA, Old LJ, Stockert E, Chen YT, et al. Immunoreactivity for A103, an antibody to Melan-A (MART-1), in adrenocortical and other steroid tumors. Am J Surg Pathol 1998;22:57-63.

33. Busam KJ, Chen YT, Old LJ, Stockert E, Iversen K, Coplan KA, et al. Expression of Melan-A (MART-1) in benign melanocytic nevi and primary malignant melanoma. Am J Surg Pathol 1998;22:976-82.

34. Chen YT, Stockert E, Tsang S, Coplan KA, Old LJ. Immunophenotyping of melanomas for tyrosinase: implications for vaccine development. Proc Natl Acad Sci U S A 1995;92: 8125-9.

35. Chen YT, Stockert E, Jungbluth AA, Tsang S, Coplan KA, Scanlan MJ, et al. Serological analysis of Melan-A (MART-1), a melanocyte-specific protein homogeneously expressed in human melanomas. Proc Natl Acad Sci U. S. A. 1996;93: 5915-9.

36. Jungbluth AA, Busam KJ, Chen TY, Stockert E, Coplan KA, Iversen K, et al. A103-an anti-Melan-A/MART-1 monoclonal antibody for the detection of malignant melanoma in paraffin embedded tissues. Am J Surg Pathol 1998;22:595-602.

37. Dalerba P, Ricci A, Russo V, Rigatti D, Nicotra MR, Mottolese $\mathrm{M}$, et al. High homogeneity of MAGE, BAGE, GAGE, tyrosinase and Melan-A/MART-1 gene expression in clusters of multiple cutaneous metastases of human melanoma: implications for protocol design of therapeutic antigen-specific vaccination strategies. Int J Cancer 1998;77:200-4.

38. McGovern VJ, Shaw HM, Milton GW, Farago GA. Lymphocytic infiltration and survival in malignant melanoma. In: Ackermann AB, editor. Pathology of malignant melanoma: Masson monographs in dermatopathology. New York: Masson Publishing; 1981. pp. 341-4.

39. Mansen MG, McCarten AB. Tumor thickness and lymphocytic infiltration in malignant melanoma of the head and neck. Am J Surg 1974;128:557-61.

40. Clemente CG, Mihm MC, Bufalino R, Zurrida S, Collini P, Cascinelli N. Prognostic value of tumor infiltrating lymphocytes in the vertical growth phase of primary cutaneous melanoma. Cancer 1996;77:1303-10.

41. Hakansson A, Gustafsson B, Krysander L, Hakansson L. Tumour-infiltrating lymphocytes in metastatic malignant melanoma and response to interferon treatment. Br J Cancer 1996;74:670-6.

42. Mihm MC Jr, Clemente CG, Cascinelli N. Tumor infiltrating lymphocytes in lymph node melanoma metastases: a histologic prognostic indicator and an expression of local immune response. Lab Invest 1996;74:43-7. 